\title{
Mesozoic Coleopteran Faunas from Argentina: Geological Context, Diversity, Taphonomic Observations, and Comparison with Other Fossil Insect Records
}

\author{
María Belén Lara, ${ }^{1}$ Oscar Florencio Gallego, ${ }^{2}$ and Lara Vaz Tassi ${ }^{3}$ \\ ${ }^{1}$ Entomología, Departamento de Biología, Facultad de Ciencias Exactas y Naturales y Agrimensura, Universidad Nacional del Nordeste \\ and Área Paleontología, Centro de Ecología Aplicada del Litoral (CONICET), Casilla de Correo 128, 3400 Corrientes, Argentina \\ ${ }^{2}$ Micropaleontología, Departamento de Biología, Facultad de Ciencias Exactas y Naturales y Agrimensura, Universidad Nacional del \\ Nordeste and Área Paleontología, Centro de Ecología Aplicada del Litoral (CONICET), Casilla de Correo 128, 3400 Corrientes, \\ Argentina \\ ${ }^{3}$ Área Paleontología, Centro de Ecología Aplicada del Litoral (CONICET), Casilla de Correo 128, 3400 Corrientes, Argentina
}

Correspondence should be addressed to Oscar Florencio Gallego, ofgallego@live.com.ar

Received 2 October 2011; Revised 30 November 2011; Accepted 14 December 2011

Academic Editor: Ai-Ping Liang

Copyright ( 2012 María Belén Lara et al. This is an open access article distributed under the Creative Commons Attribution License, which permits unrestricted use, distribution, and reproduction in any medium, provided the original work is properly cited.

The order Coleoptera is the most diversified group of the Class Insecta and is the largest group of the Animal Kingdom. This contribution reviews the Mesozoic insects and especially the coleopteran records from Argentina, based on bibliographical and unpublished materials ( 86 described species, 526 collected specimens). The material came from different geological units from the late Middle Triassic to the Late Triassic (Bermejo, Cuyo, and Malargüe basins) to the Middle-Late Jurassic and Early Cretaceous (Deseado Massif, Cañadón Asfalto, and San Luís Basin). The coleopteran record is composed of 29 described species with 262 collected specimens (isolated elytra) mainly represented by Triassic species and only four specimens recorded in Jurassic units, all of them currently unpublished. These fossil coleopterans provide fundamental information about the evolution of insects in the Southern Hemisphere and confirm the Triassic Argentinean insect deposits to be among the most important in the world.

\section{Introduction}

Continental invertebrate communities from the Mesozoic Era are represented principally by two phyla: Arthropoda and Mollusca. Arthropods constitute the most abundant and diverse fossil record in lacustrine sequences of Argentina with "conchostracans", insects and ostracods as most representative groups. The mollusks, represented by bivalve and occasionally gastropods, have a low diversity and restricted distribution [1].

The recent insects constitute the richest class in terms of species diversity with estimates ranging from 3 to 50 million species [2-5]. There are 1275 families of known insects in the fossil record and 967 presently existing, of which $70 \%$ are also known as fossils $[6,7]$. The data from insect fami- lies/genera indicate that the group's growth model follows an exponential curve of evolution, contrary to the occurrence of new orders, which declines $[8,9]$.

The Coleoptera represents the most diverse order within the Class Insecta, both taxonomically and ecologically. In addition, it is the most specious group in the Animal Kingdom with the number of described modern species exceeding 350,000 , representing about $40 \%$ of the known insect fauna [10]. This diversity is probably related to certain features that allow adult living in restricted niches while retaining their ability to fly [10].

The systematics and phylogeny of fossil beetles is a very complex area, with old and new proposals and numerous publications which surprisingly still not clear this question. Most studies use different methodologies and are based 
mainly on adult morphology and rarely use immature stages of ontogenetic development. The basis of modern classification of fossil coleopterans was initially established by Crowson $[10,11]$.

The oldest record of the Coleoptera is from Paleozoic Era: Lower Permian deposits of the Wellington Formation from Oklahoma and Kansas (USA) [12, 13], Obora (Czech Republic) $[14,15]$, and the Chekarda, Ural region (Russia) [16].

Mesozoic beetles were much more common and diverse than Paleozoic; geological information shows that beetles have had a dominant record among the group of insects since early Jurassic [16]. However, further information still remains elusive as the Mesozoic beetles are less informative, because of isolate elytra, than those of the Paleozoic [11]. The Mesozoic associations consisted mainly of xylophagous forms and larval stages have been found in numerous localities, except in the Upper Cretaceous.

The aim of this paper is to present the record of abundance and diversity of Mesozoic beetles in Argentina. The information comes from a bibliographic compilation and stud$y$ of materials found in recent paleontological expeditions conducted by our research group. At the same time, we provide information on the geology and age of localities where the material was collected and present a comparison with other Mesozoic groups of insects collected in Argentina and contemporary faunas from southern Hemisphere. Finally, it provides paleobiogeographic information and highlights the importance of beetles in understanding the evolution of the Mesozoic after the Permian Triassic extinction event.

Our analyses are based primarily on elytra in the Upper Triassic localities from Argentina, which provide a significant amount of information for Coleoptera and allow to have a vision of the composition of the assemblages about 252 million years ago. Cretaceous and Jurassic materials are mentioned in passing, and their study is in progress.

\section{Previous Coleopteran Records}

Contributions involving the study of beetles in Mesozoic continental sediments of Argentina began with Frenguelli $[17,18]$, who observed small curculionid elytra in shale samples from southwestern Mendoza Province (stratigraphical levels unknown) and other beetle elytra originating from various levels of the Ischigualasto Formation (probably levels of the Los Rastros Formation sensu Stipanicic and Bonaparte [19]), San Juan Province. Fossa-Mancini [20] reported the presence of galleries related to burrowing larvae of certain xylophagous beetles in silicified trunks from Upper Cretaceous of Patagonia. Feruglio [21] mentioned fossil beetles represented by silicified incomplete elytra, thorax, and abdomen remains, probably attributable to the Elateridae, from Laguna del Molino locality (Gran Bajo de San Julián) in Santa Cruz Province.

Subsequently, Genise [22] presented a description of different ichnofossils found in fossil trunks and fructifications from the Upper Cretaceous of Rio Negro Province, assigned to the probable activity of beetle and termites larvae. Further, Genise and Hazeldine [23] described insect traces in fossil wood from La Matilde Formation from the Jurassic Petrified Forest of Jaramillo in Santa Cruz Province, probably assigned to the activity of buprestid larvae. Martins-Neto and Gallego [24] disclosed the remains of beetles consisting of isolated elytra and body parts from the La Matilde Formation of Gran Bajo de San Julián in Santa Cruz Province, assigned mainly to Caraboidea. Gallego et al. [25] reported a second discovery of fossil beetles as Argentinocupes and Argentinosyne and other insects as blattids and hemipterans in the Bermejo Basin in San Juan Province and the first record from the upper Los Rastros Formation of this basin.

The Order Coleoptera was also treated in the works of Martins-Neto et al. [26-30] and Martins-Neto and Gallego [31], where new Triassic species assigned to Permosynidae, Schizocoleidae, Cupedidae, and Elateridae were described. The material (elytra) was collected in Ischichuca and Los Rastros Formations of the Bermejo Basin in La Rioja Province and Potrerillos and Cacheuta Formations, Cuyo Basin of Mendoza Province. Monferran et al. [32] mention a new locality with a record of Coleoptera: Estancia Fossati, Puesto Almada Member of the Cañadón Asfalto Formation, from Middle to Late Jurassic in age. Brauckmann et al. [33] describe two elytra of Permosynidae (Ademosyne rosenfeldi and Ademosyne llantenesensis) from the Llantenes Formation of the Malargüe Basin, Mendoza Province.

\section{Material and Methods}

Triassic specimens from the Cuyo Basin originate from three areas: (a) south of Cerro Cacheuta at the Puesto Miguez, Quebrada del Durazno and Agua de las Avispas localities, in Potrerillos and Cacheuta strata of the Upper Triassic; (b) north of Cerro Bayo at the Quebrada del Cerro de las Cabras locality in Cerro de las Cabras Formation of the Middle Triassic and Quebrada del Puente locality in Potrerillos Formation of the lower Upper Triassic; and (c) southeast of Cerro de los Colorados, Paramillos de Uspallata, in strata of the Cacheuta Formation (Upper Triassic).

In the Malargüe Basin, material was collected from the upper portion of the Llantenes section of the Llantenes Formation (Late Triassic). In the Bermejo Basin, the fossil insects come from Río Gualo, Picos Gemelos, Agua Escondida, Quebrada de Ischichuca Chica, and Chañares localities, belonging to Los Rastros (early Late Triassic) and Ischichuca (late Middle Triassic to early Upper Triassic) Formations, in La Rioja Province.

Jurassic beetles were collected from the La Matilde Formation of Middle to Late Jurassic ages, Laguna del Molino locality (Gran Bajo de San Julián), and from Estancia El Malacara locality (Bahía Laura), from Santa Cruz Province, and the Cañadón Asfalto Formation, of Middle to Late Jurassic age, from the Estancia Fossati locality, Chubut Province.

Cretaceous insects originate from the Anfiteatro de Ticó Formation, of the Baqueró Group, Bajo Grande, in Santa Cruz Province and La Cantera Formation, Gigante Group, in San Luis Province; both are from the Early Cretaceous.

It is important to emphasize that material collected in the Potrerillos-Cacheuta sequences during an expedition occur- 
ring in April of 2010 was included in our analyses, as was Jurassic specimens from Chubut Province, collected during a 2009 fieldtrip and material from the Los Rastros Formation. This newly discovered material is important for understanding beetle evolution in Argentina during the Mesozoic because it is so diverse, abundant and well preserved.

The material cited in the literature is deposited in the paleontological collection with the acronyms PULR-I (Invertebrate Paleontological Collection, Universidad Nacional de La Rioja, La Rioja Province), CTES-PZ (Paleozoological Collection of the Universidad Nacional del Nordeste, Corrientes Province), MCNAM (Museo de Ciencias Naturales y Antropológicas “J. C. Moyano", Mendoza Province), MHINUNSL-GEO (Museo de Historia Natural de la Universidad Nacional de San Luis, San Luis Province), MLP (Museo de La Plata, Invertebrate Paleontology, La Plata, Buenos Aires Province), and CORD-PZ (Palaeozoological Collection, Universidad Nacional de Cordoba, Córdoba Province).

\section{Mesozoic Insects Record from Argentina}

Most information on the Mesozoic insect faunas of Argentina comes from the Triassic Period and, above all, from collections made of the Los Rastros Formation, Bermejo Basin (La Rioja), and Potrerillos Formation, Cuyo Basin (Mendoza). Both provide $90 \%$ of the total abundance of insects in Argentina, constituting one of the most important records of continental life developed in Gondwana. In addition, these basins are known for their large extent, exceptional outcrops, well-developed stratigraphy columns, and the wealth of their taphofloras and vertebrate faunas.

In Argentina, knowledge of Mesozoic insects has made remarkable strides in recent years, having as a background the works published by Wieland [34, 35], Tillyard [36], and Cabrera [37] on fossil insects from the Cacheuta and Potrerillos Formations of early Late Triassic age. So far, 86 species in 27 families of 12 orders have been described from 526 samples collected (Figure 1). The fossil insect fauna of Argentina comes from stratigraphic levels of continental sediments assigned to the interval between the upper Middle Triassic to Lower Cretaceous.

\subsection{Insects Records and Geological Context (Figure 2)}

4.1.1. Triassic. The fossiliferous potential of the Argentina Triassic units is highly significant, based on 510 collected specimens and 81 described species. The insect record comes from Los Rastros and Ischichuca Formations of the Bermejo basin, La Rioja Province; Potrerillos, Cacheuta, and Cerro de las Cabras Formations of the Cuyo Basin, Mendoza Province; and Llantenes Formation of the Malargüe Basin, southern Mendoza Province (Figure 3).

The Cuyo Basin of central western Argentina is composed of thick sedimentary sequences from the Middle to Late Triassic that constitute the Uspallata Group. These units have a rich and well-known Dicroidium flora, as well as a microflora and a fauna as invertebrates, fishes, and tetrapods that are interpreted as dwelling in fluvial-lacustrine systems. Insect collections of coleopterans, blattids, hemipterans,

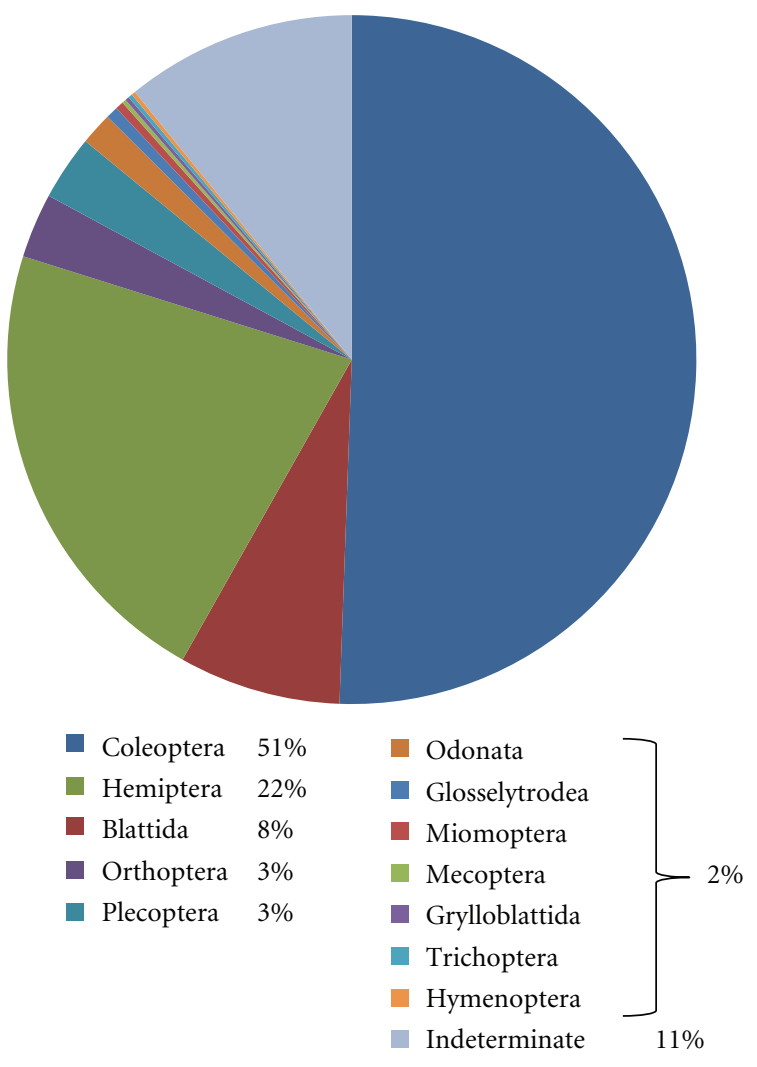

Figure 1: Pie-chart showing the abundance of Mesozoic specimens from Argentina, grouped by taxonomic order.

miomopterans, orthopterans, trichopterans, plecopterans, odonatans, and grylloblattids originate from the Cerro de las Cabras Formation (1 specimen), the Potrerillos Formation (21 described species and 229 collected specimens), and the Cacheuta Formation ( 2 described species and 27 specimens) [29, 30, 39-43].

The Malargüe Basin of southern Mendoza Province includes Choiyoi volcanic and overlain siliciclastic deposits. The insect fauna was collected from the upper section of the Llantenes Formation (Late Triassic) which is built of two coarsening-upward cycles reflecting a deltaic progradation of a fluvial into a lacustrine environment (lower part), succeeded by repeated progradation into a floodplain dominated environment (upper part; with insects, conchostracans, fish, and plants remains). The insect remains includes 2 coleopteran elytra and 1 mecopteran, and these news finds represent the youngest Triassic occurrence from Argentina and South American and the second youngest record from the Southern Hemisphere [33].

The Los Rastros and Ischichuca Formations (Agua de la Peña Group, La Rioja Province) are part of the Bermejo Basin (Ischigualasto-Villa Unión Basin), an extant basin located in northwestern Argentina. The Los Rastros Formation of early Late Triassic age is a lacustrine-deltaic that consists of several sedimentary cycles of black shales, siltstones, and sandstones. The succession is characterized by record of five plants, four invertebrates, and four vertebrates taphofacies [44]. The 


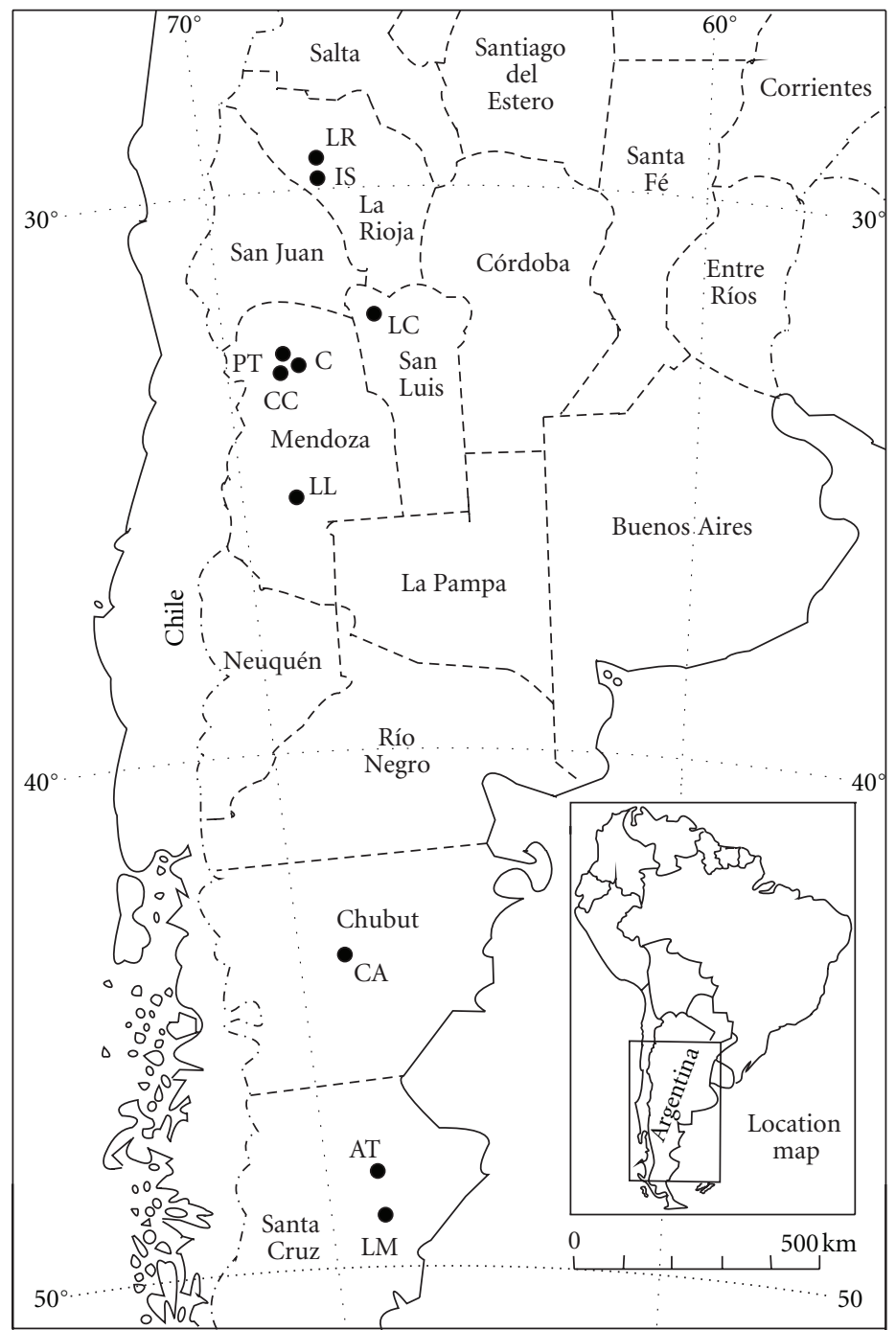

FIgURE 2: Map showing the Mesozoic units and outcrop areas approximately that carried the insect fauna mentioned in the text. AT: Anfiteatro de Ticó; C: Cacheuta; CA: Cañadón Asfalto; CC: Cerro de las Cabras; IS: Ischichuca; LC: La Cantera; LL: Llantenes; LM: La Matilde; LR: Los Rastros; PT: Potrerillos. (modified from Zavattieri [38]).

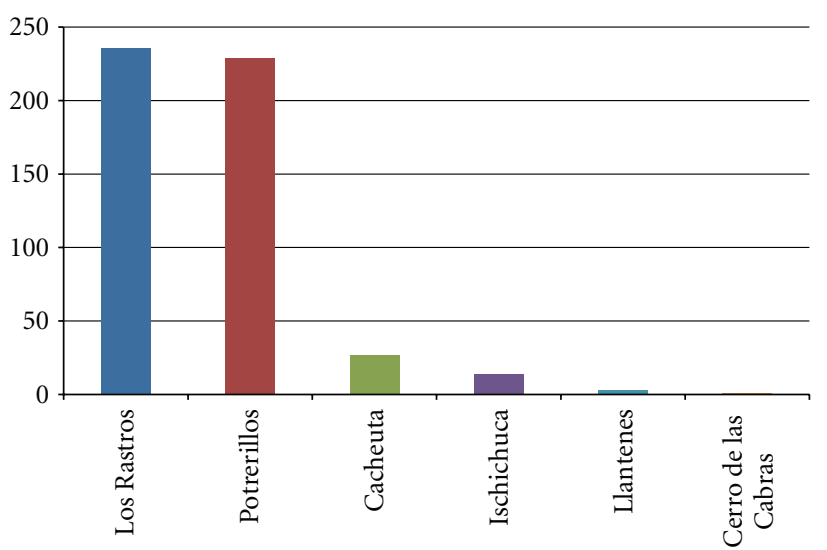

FIGURE 3: Bar graphic showing the abundance of specimens in different Triassic insect localities. (Note: included new undescribed materials). insect record consists of 44 described insect species and 236 collected specimens and is comprised of coleopteran elytra and wing remains of blattids, plecopterans, miomopterans, orthopterans, glosselytrodeans, and odonatans $[26,27,42$, $45]$

The Ischichuca Formation of late Middle Triassic to early Late Triassic age is predominantly composed of shallow and deep lacustrine facies with progradational deltaic successions, that starts to begin as fanglomerates with sandstones and tuffitic intercalations and continue with dark carbonaceous shales alternating with sandstones and pelitic and tuffaceous strata. In particular, insect remains are found in dark brown to olive-green claystones with abundant plant remains from the middle to the basal upper parts of the unit. This interval is interpreted as a shallow, partly saline lake (interpreted from a perennial playa lake association facies, L2 from Melchor [46, 47]) that ranges to a deep freshwater lake (deep freshwater lake association facies, L3 from Melchor [46, 47]). 
The fossil insects, consisting of 11 described species and 14 specimens, comprise a blattid wing and coleopteran elytra $[31,41,48]$.

4.1.2. Jurassic. The Jurassic insect fauna from Argentina (Table 1) is less well known than the Triassic one and also sparse when compared with other Jurassic localities of the world. This rarity is due to its restricted geographic distribution and low species diversity and is related to the low number of collections and studied localities.

The first contribution probably was made by Frenguelli [18] who mentioned and illustrated the "rare insect remains" of a paleohemipteran wing from the "Estancia El Malacara" from Bahia Laura, in Santa Cruz, Province. In the 1990s one of us (O. F. Gallego) and Rafael Martins-Neto restudied this specimen and concluded that it is probably not an insect. Later, Feruglio [21] reported the presence of silicified coleopteran remains from the Laguna del Molino locality of Gran Bajo de San Julian, in Santa Cruz Province) associated with plant fragments, bones, freshwater mollusks, and conchostracans. These previous contributions of insect reports were summarized by Gallego and Martins-Neto [49], Martins Neto and Gallego [24, 50], Monferran et al. [32, 51, 52], Genise et al. [53], and Gallego et al. [54] who reported new finds of insects from the orders Coleoptera (elytra and body remains), Heteroptera (fragmentary wings), and Trichoptera (wing fragments and larval cases) from both the La Matilde Formation of the Laguna del Molino locality and Cañadón Asfalto Formation of Cerro Cóndor and Estancia Fossati localities. These records are associated also with gastropods, bivalve mollusks, ostracods, conchostracans, plants, and fish remains. Other Jurassic insect records such as the presence of chironomid head capsules and larval cases [55] and mecopterans (Bittacidae) with complete bodies [56] come from Gan Gan locality of the Cañadón Asfalto Formation in Chubut Province.

The Jurassic fossil insect record from Argentina comes from two geological units: the La Matilde Formation (late Middle Jurassic, Santa Cruz Province) and the Cañadón Asfalto Formation of late Middle Jurassic to Late Jurassic age, Chubut Province.

The late Middle Jurassic La Matilde Formation comprises a volcaniclastic sequence that bears silicified woods (ferns and gymnosperms), a taphoflora, invertebrates, and tetrapods. The sediments show a typical continental sequence of a low-energy fluvial system, with lentic water bodies under reduced conditions within a floodplain environment, influenced by intensive volcanism evidenced by pyroclastic deposits [57].

The Cañadón Asfalto Formation of Middle-Late Jurassic age is a thick sedimentary sequence with volcanic intercalations that constitutes one of the most important nonmarine Jurassic records from South America. Two members can be distinguished, the lower one, the Las Chacritas Member, and the upper one, the Puesto Almada Member [58]. The insects were found in the upper member and particularly from the locality "Estancia La Sin Rumbo", an assemblage of "con-
TABLE 1: Mesozoic insects from Argentina.

\begin{tabular}{lcccc}
\hline Order & Triassic & Jurassic & Cretaceous & Mesozoic insects \\
\hline Coleoptera & 262 & 4 & 6 & 266 \\
Hemiptera & 104 & 4 & 1 & 114 \\
Blattida & 39 & & 1 & 40 \\
Orthoptera & 16 & & 16 \\
Plecoptera & 16 & & & 16 \\
Odonata & 7 & & & 8 \\
Glosselytrodea & 3 & & 2 \\
Miomoptera & 2 & & & 1 \\
Mecoptera & 1 & & & 1 \\
Grylloblattidae & 1 & & & 1 \\
Trichoptera & 1 & & & 57 \\
Hymenoptera & 1 & & & 526 \\
Indeterminate & 57 & & & \\
\hline Total & 510 & 8 & & \\
\hline
\end{tabular}

chostracans", ostracods, bivalves, and caddisfly cases. This assemblage occurs in the upper part of a volcaniclastic lacustrine sequence consisting of yellowish tuffs and tuffites providing evidence of dry climatic conditions. The assemblage recorded from the Estancia Fossati locality came from three levels consisting of shales, limestones, and tuffs, associated with invertebrates such as bivalve mollusks, insect larval cases, ostracods, conchostracans), and fish scales. The Estancia Fossati faunas represent low-energy shallow freshwater environments within associated plant communities $[54,59]$.

4.1.3. Cretaceous. The poorly known Cretaceous insect fauna from Argentina is reflected by only 5 described species and only 8 collected specimens (Table 1). These records are based on two Early Cretaceous localities: (a) the Anfiteatro de Ticó Formation, Bajo Grande locality, from Santa Cruz Province, and (b) the La Cantera Formation, Gigante Group of San Luis Province.

The Anfiteatro de Ticó Formation of the Baqueró Group is composed by siliciclastic and volcaniclastic deposits [60] and the insect fauna consisting of the species Blattulopsis popovi (Blattida) [61] and Argentinopetala archangelskyi (Odonata) [62].

The La Cantera Formation of the Gigante Group exhibits greenish to gray limonite and arcilite with intercalated red sandstones and shales in the upper part [63]. The La Cantera assemblage is composed of a large, diverse association of ostracods, insects (hemipterans, orthopterans, coleopterans and caddisfly larval cases), palynomorphs, plants (leaves and sphenopsid reproductive organs), and fish fragments [64]. The paleontological content of this deposit suggests a lakeshore environment, attributable to fish taxonomic diversity and the poor state of terrestrial insect preservation [65]. Insect remains comprise of Canteronecta irajae (Naucoroidea) [66], Rhomboidella popovi (Corixidae) [67] and 
Notonecta mazzoniae (Notonectidae) [65]. Also are recorded the poorly preserved orders Coleoptera, Orthoptera, and Trichoptera.

\section{Mesozoic Coleopterans from Argentina}

The analysis of Coleoptera used information obtained from previous publications [21, 26-33, 39, 44]. Information was also obtained from observation of new unpublished material collected in the 2010 expedition to the Potrerillos Formation of Mendoza Province (Figures 4(f)-4(r)), Los Rastros Formation of La Rioja Province, and Jurassic specimens from Cañadón Asfalto Formation of Chubut Province.

Coleoptera is the most abundant and exhibits the greatest speciosity among Mesozoic insect fauna in Argentina. Until now, 262 specimens have been collected, covering about $50 \%$ of the total abundance, and 29 species have been described, including the permosynids Ademosyne umutu, A. Ilantenesensis, A. rosenfeldi, A. arcucciae (Figure 4(c)), A. punctuada (Figure 4(d)), A. elongatus, A. hexacostata, Ademosyne sp. 1, Ischichucasyne cladocosta, and Delpuentesyne menendezi; the schizocoleids Argentinosyne ischichucaensis, A. duraznoensis, A. bonapartei, A. frengüelli (Figure 4(b)), A. rugosa, A. gualoensis, A. gonaldiae, and A. losrastrosensis, Gen. et sp. indet. 1 and 2; the elaterids Babuskaya elaterata, Gemelina triangularis, Cardiosyne obesa, C. elegans; the cupedids Argentinocupes sara, A. pulcher (Figure 4(a)), and A. abdalai (Figure 4(e)); and two specimens Gen. et sp. indet. 1 tentatively assigned to the Permosynidae family and other specimen (Gen. et sp. indet. 1) of uncertain position.

From an analyses of the information about Triassic beetles, the best represented groups are families Permosynidae (135 specimens) and Schizocoleidae (40 specimens); the genera Ademosyne (129 specimens) and Argentinosyne (39 specimens); and the species Ademosyne arcucciae (96 specimens, Figure 4(c)) and Ademosyne hexacostata (17 specimens). Ninety-eight percent of the specimens collected are from Triassic continental sedimentary rocks, from Los Rastros Formation (69\% of total abundance), Potrerillos Formation (17\%), Cacheuta Formation (9\%), Ischichuca Formation (4\%), and Llantenes and Cerro de las Cabras Formations $(2 \%)$.

The beetles preserved in the various localities appear as complete impressions, body part impressions (abdomens, thoraces), and as elytra moulds that can be complete or fragmentary, articulated or disarticulated, smooth or striated, with or without ornamentation.

Two analyses were performed. The first considered the state of preservation, namely, if the specimen was complete/incomplete, and its degree of articulation/disarticulation. For these measurements, there were used 262 elytra distributed in the different formations as shown in Table 2.

The beetle fauna consists mainly in complete and disarticulated elytra (211 samples; Figures 4(a), 4(d), 4(f)-4(1), $4(n)-4(r))$, followed by incomplete and disarticulated elytra (41 samples), complete and articulated elytra (8 samples; Figures 4(b), 4(c), 4(e), 4(m)), and last incomplete and articulated elytra (2 samples) (Figure 5).
In the second analysis, elytra ornamentation was observed, used in describing the following specimens: 187 specimens from Bermejo Basin and 8 from Malargüe and Cuyo Basins. Accordingly, the ornamented elytra may be smooth (46 specimens; Figures 4(b), 4(f), 4(g), 4(k), 4(l), $4(\mathrm{~m}), 4(\mathrm{o}), 4(\mathrm{q})$ and $4(\mathrm{r}))$ or striated (149 specimens; Figures $4(\mathrm{a}), 4(\mathrm{c})-4(\mathrm{e}), 4(\mathrm{~h}), 4(\mathrm{i}), 4(\mathrm{n}), 4(\mathrm{p}))$. In the case of striated elytra, costae may be smooth (91\%; Figure $4(\mathrm{c}))$, punctuate (6\%; Figure $4(d))$, or granular $(3 \%)$. The number of costae can vary between 6 and 11. Elytra also can have ornamentation (173 specimens) or lack it (22 specimens). Lastly, the ornamentation can be granular (93\%; Figure $4(\mathrm{c})$ ), rough $(5 \%)$, with rows of cells $(1 \%$, Figure $4(\mathrm{a}))$, or striated $(1 \%)$.

5.1. Jurassic and Cretaceous Coleopterans. Knowledge of beetles and of insects in general from Jurassic and Cretaceous sediments in Argentina is poorly developed. This absence of data highlights the importance of exploring for new fossil insect localities. In general, beetles are only referenced in works that treat other insect groups. By contrast, information generated for the Jurassic and the Cretaceous of Argentina will allow its characterization and comparison with other continental faunas from the Southern Hemisphere (South America, Antarctica, and Australia), currently which are better known. Therefore, owing to the scarce information about the Jurassic and Cretaceous specimens, the present study has considered only examination of Triassic material.

\section{Comments on Other Insect Orders from Argentina (Figure 6)}

Hemiptera is the second most common order in the Mesozoic from Argentina with 114 specimens collected (22\%) and 19 described species from various assemblages. The material is preserved as impressions of wings (fore or hind, complete or fragmentary, with or without a clavus) and occasionally complete bodies of insects, most attributable to the families Dysmorphoptilidae (9 specimens) and Scytinopteridae (7 specimens); the genus Gallegomorphoptila (9 specimens); and the specie Gallegomorphoptila acostai (5 specimens). For the rest of the Mesozoic, there are only three recorded Cretaceous species: Canteronecta irajae (Naucoroidea) [66], Rhomboidella popovi (Corixidae) [67], and Notonecta mazzoniae (Notonectidae) [65].

The Blattida (cockroaches) includes 40 specimens (7\%) and 18 species, preserved as disarticulated tegmina (complete or fragmentary, with missing or not the clavus). The assemblage is dominated by the families Mancusoblattidae and Mesoblattinidae (10 specimens) and by the genus Hermosablatta (9 specimens). The species Samaroblatta corrientesina, S. gualoensis, Hermosablatta crassatella, H. pectinata, Lariojablatta neiffi, and Condorblatta lutzae are the most abundant taxa. The Blattulopsis popovi species occurs in the Lower Cretaceous of Santa Cruz Province [61].

The rest of the orders, Plecoptera and Orthoptera with 16 specimens, Odonata with 8 specimens, Glosselytrodea with 
Triassic coleopterans from Argentina
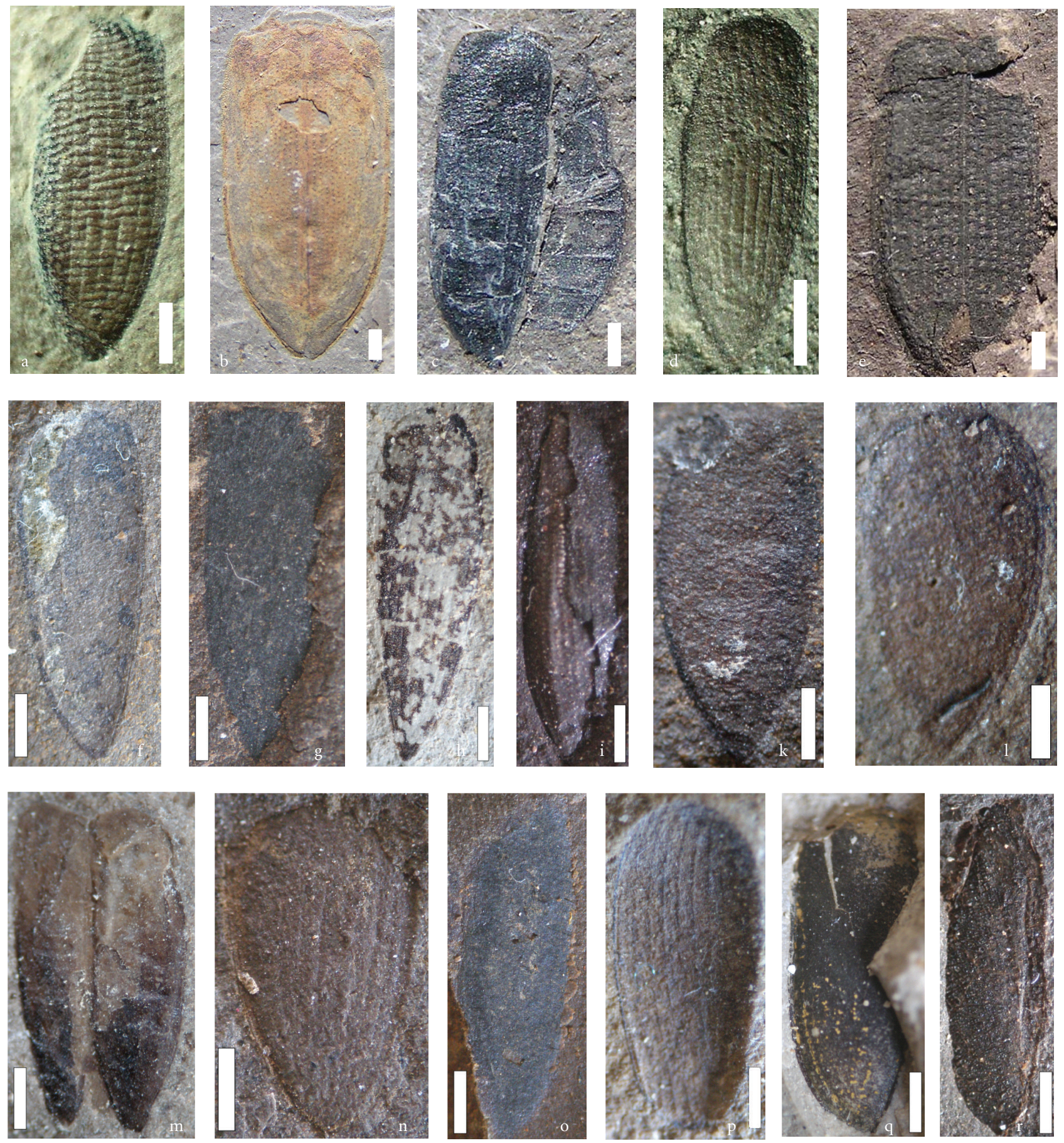

FIgURE 4: Examples of fossil insects collected from Triassic insects localities, Western Argentina, illustrating the stage of preservation seen in the localities. (a) Argentinocupes pulcher, complete desarticulated elytron. (b) Argentinosyne frengüelli, complete articulated elytron. (c) Ademosyne arcucciae, complete articulated elytron and thoracic and abdominal elements. (d) Ademosyne punctuada, complete desarticulated elytron. (e) Argentinocupes abdalai, complete articulated elytron (Martins-Neto et al., [27]); (f)-(r) Indet. material: complete articulated elytron (m) and complete desarticulated elytron ((f)-(l), (n)-(r)). Ornamentation of elytra: smooth ((b), (f), (g), (k), (l), (m), (o), (q), (r)) and striate ((a), (c)-(e), (h), (i), (n), (p)). Scale bar: $1 \mathrm{~mm}$. 
TABLE 2: State of preservation of the Triassic beetles.

\begin{tabular}{|c|c|c|c|c|c|c|}
\hline \multirow{2}{*}{ Elytron } & \multicolumn{6}{|c|}{ Formation } \\
\hline & Los Rastros & Ischichuca & Potrerillos & Cacheuta & L1antenes & Cerro de las Cabras \\
\hline Articulated complete & 5 & 0 & 3 & 0 & 0 & 0 \\
\hline Articulated incomplete & 2 & 0 & 0 & 0 & 0 & 0 \\
\hline Disarticulated complete & 140 & 5 & 41 & 24 & 1 & 0 \\
\hline Disarticulated incomplete & 33 & 5 & 0 & 1 & 1 & 1 \\
\hline Total & 180 & 10 & 44 & 25 & 2 & 1 \\
\hline
\end{tabular}

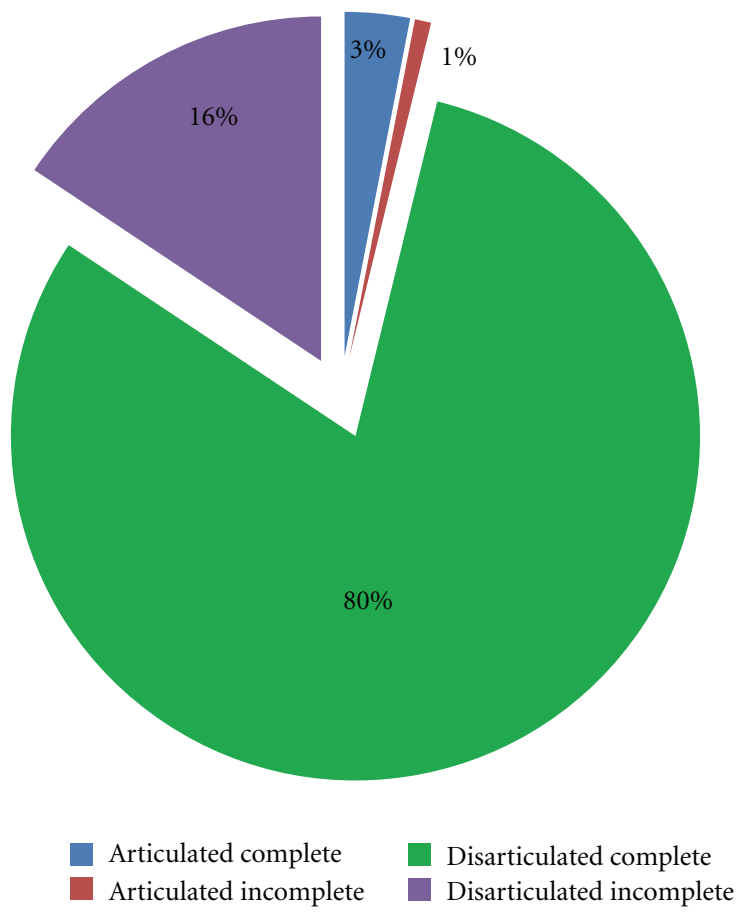

FIGURE 5: Pie-chart showing the relative percentage of specimens from beetle locality collection, grouped by element type.

3, Miomoptera with 2 specimens, and Mecoptera, Grylloblattida, Trichoptera, and Hymenoptera, all with one specimen each, constitute $9 \%$ of the total abundance of the material collected. Each one is represented by a handful of impressions of fore wings and complete or fragmentary bodies of nymphs such as head and abdominal sclerites.

The label "indeterminate" record (57 specimens, 11\%) includes the complete, incomplete or poorly preserved elements, in which we were unable to be confidently assigned to any particular order or alternatively it is under study. They are represented by impressions of wings (complete or fragmentary), some elements associated with abdominal sclerites and partial bodies.

\section{Paleoecology and Taphonomy}

Given the aforementioned information on the Mesozoic insect fauna of Argentina, the material recovered includes disarticulated and fragmentary specimens (evidence of postmortem transportation) approximately $97.5 \%$ of which comprises mostly impressions of wings of hemipterans and blattids, elytra of beetles, and other isolated body parts (thoraces, abdomens, appendages) of the Orthoptera, Mecoptera, Grylloblattida, Plecoptera, Trichoptera, Miomoptera, Odonatoptera, Hymenoptera, and Glosselytrodea, in addition to head capsules and dwelling tubes of chironomid and caddisfly cases.

From an ecologic perspective, the analysis of this fauna shows that most groups have a subaerial or terrestrial habit as adults, and some are represented by immature (often aquatic forms), such as the Plecoptera, Grylloblattida, Hemiptera, and Odonata. This implies that the fossil record is biased by the absence of other autochthonous aquatic forms, the causes of which required future inquiry.

\section{Final Considerations}

Fossil beetles are one of the most interesting objects in paleontological and stratigraphical research, but they remain poorly understood, as they are difficult to study [68]. The great diversity and abundance that occurs in the fossil record is probably correlated with the composition of the elytra and its shape preservation, appearing as elytra moulds that can be articulated or disarticulated.

In South America, the previous literature reviews and the analyses of unpublished material indicate the relevance of Triassic and Tertiary beetle records. Nevertheless, the group is poorly studied and the intensity of collections is low. Therefore, it requires much more skilled work.

The record (Table 3) is restricted to continental sediments from Brazil, Argentina, Chile, and Peru. In Brazil, 17 species were discovered and come from Early to Middle Permian ages of Irati Formation $[69,70]$ and from Middle to Late Triassic ages of the Santa María Formation [71] of the Paraná Basin, from the Early Cretaceous age of Santana Formation in Araripe Basin [72-75], from the Oligocene age of Tremembé Formation in Taubate Basin and Fonseca Formation in Fonseca Basin [76-78]. In Argentina the order is restricted to Late Triassic age with twenty nine species described [25-31, 33] from Los Rastros and Ischichuca Formations in La Rioja Province, the Cortaderita Formation in San Juan Province, the Potrerillos, Cacheuta, Cerro de las Cabras, and Llantenes Formation in Mendoza Province; Middle to Late Jurassic ages of the La Matilde Formation in Santa Cruz Province and the Cañadón Asfalto Formation in Chubut Province $[21,24,32]$; Middle to Late Eocene 
Triassic insects from Argentina
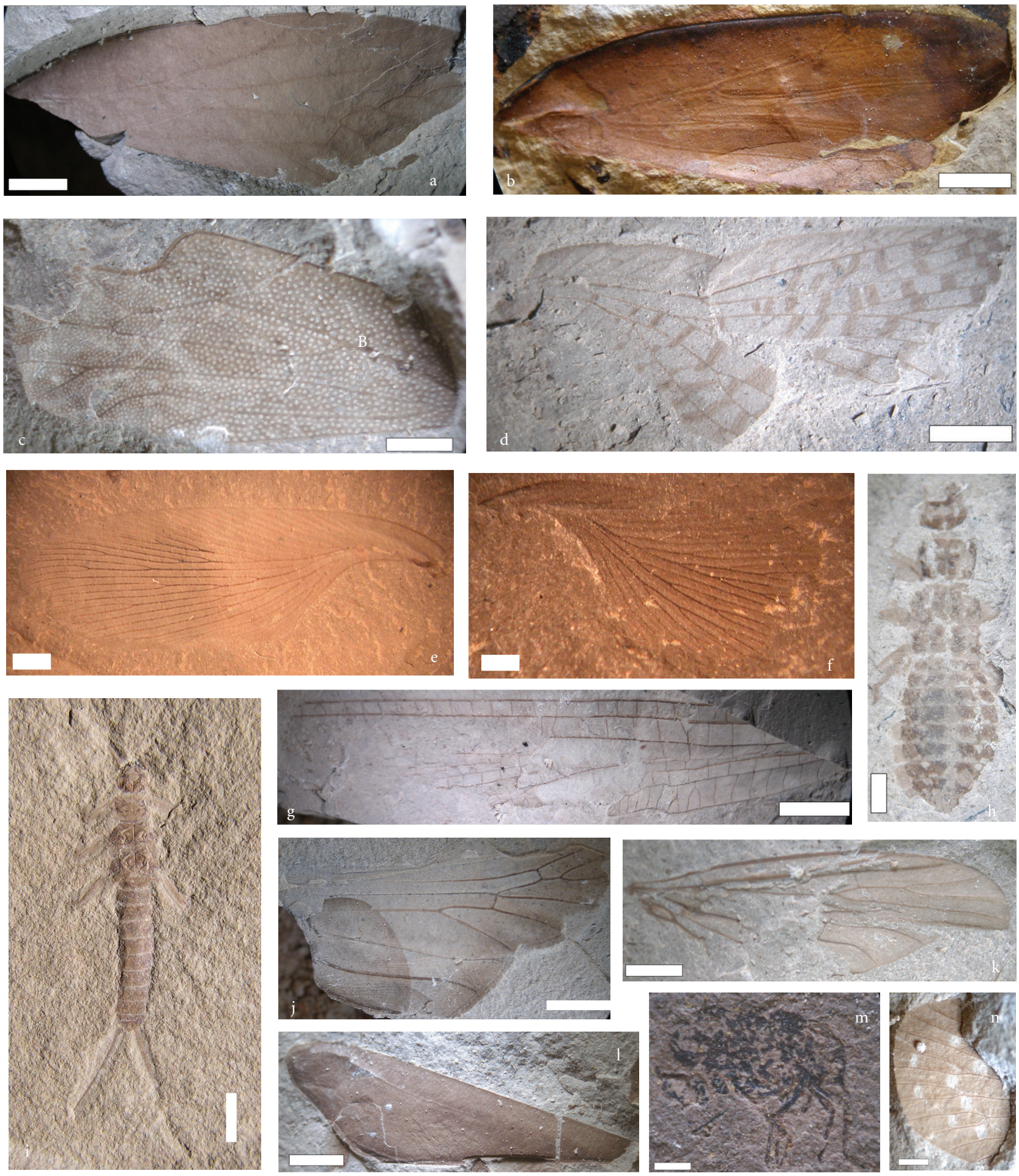

FIgure 6: Examples of fossil insects collected from Triassic insects localities, Western Argentina, illustrating its diversity and the stage of preservation (impression) seen in the localities. (a), band (c): Hemiptera. (d): Orthoptera. (e): Mancusoblatta pulchellaand (f): Hermosablatta crassatella (Blattida), Martins-Neto et al., [45]. (g) and (h): Odonata adult and nymph, respectively. (i): Platyperla marquati (nymph), Gallego et al., [54]. (j), (k), (m), and (n): indet. material. l: Hemiptera clavus. Scale bar: $1 \mathrm{~mm}$ (except (a), (b), (c), and (i): 2 mm). 
Table 3: Main stratigraphic units and beetle localities in South America.

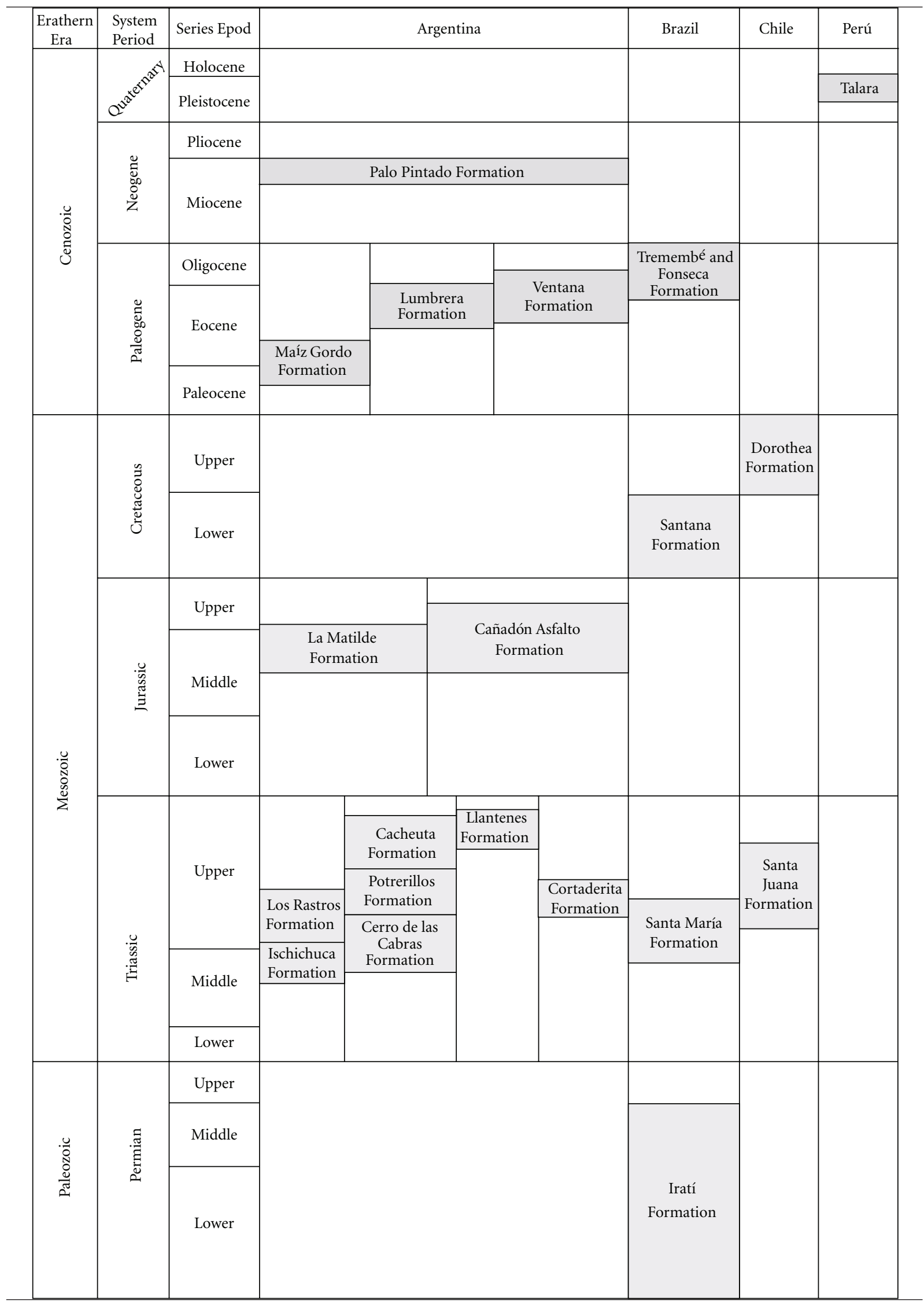


ages from the Lumbrera Formation (Grupo Salta) in Salta Province [79]; Late Paleocene to Early Eocene age from the Maíz Gordo Formation in Jujuy Province with thirty one species [80-84]; Eocene to Early Oligocene age from the Ventana Formation in Neuquen Province [85]; and Late Miocene age from the Palo Pintado Formation in Salta Province [86]. In Chile the material just comes from Santa Juana Formation of Late Triassic age with one species [87] and Dorothea Formation of Upper Cretaceous [88]. In Peru the specimens come from the Pleistocene tar-seeps of Talara in Piura Province [89].

The Mesozoic localities in Argentina, typically from the Triassic Period, have proven to be rich in fossil insect material; recent findings of insects in the strata of the Cuyo Basin have increased the number of taxa represented to currently 510 specimens. This makes Argentina one of the most important paleoentomologic regions not only in South America but also generally in the Southern Hemisphere, such as the Triassic sequences already known from Australia and South Africa.

All the knowledge provides invaluable information about the composition of the Mesozoic biota, essential for understanding biological processes that different groups of organisms experienced after the great Permian extinction event about 252 million years ago. In addition, time series of taxa within lineages could provide data for understanding beetles evolution.

\section{Acknowledgments}

The authors would like to especially thank Ana María Zavattieri for her friendship, field-work support, and contributions to the knowledge of the Triassic Biota. Also thanks go to their friend and brother Rafael Gioia Martins-Neto for being greatly responsible for the present knowledge of Triassic insect faunas from South America. They also acknowledge Tom De Vries and Carsten Braukmann and Finnegan Marsh (as journal reviewer) for all suggested improvements to this paper. This contribution was partially supported by the Consejo Nacional de Investigaciones Científicas y Técnicas, Secretaría General de Ciencia y Técnica, Universidad Nacional del Nordeste, and by the Agencia Nacional de Promoción Científica y Tecnológica (Grants PI-64/04 and PI-075/07 and PI-2010/F022; PIP-CONICET 5581; PICTO-UNNE 0226/07 to O. F. Gallego and PIP-CONICET- 5760 and 112-20100100034 to Nora Cabaleri).

\section{References}

[1] O. F. Gallego, M. J. Carmona, and R. G. M. Neto, "Nuevos avances en el conocimiento de los invertebrados fósiles del Triásico de la Argentina," in Proceedings of the Reunión de Comunicaciones Científicas y Tecnológicas, Secretaría General de Ciencia y Técnica, Universidad Nacional del Nordeste, Resistencia, Argentina, 2002.

[2] T. L. Erwin, "Tropical forests: their richness in Coleoptera and other arthropod species," Coleopterists Bulletin, vol. 36, no. 1, pp. 74-75, 1982.
[3] R. M. May, "How many species are there?" Nature, vol. 324, no. 6097 , pp. 514-515, 1986.

[4] K. J. Gaston, "The magnitude of global insect species richness," Conservation Biology, vol. 5, no. 3, pp. 283-296, 1991.

[5] K. J. Gaston, "Regional numbers of insect and plant species," Functional Ecology, vol. 6, no. 3, pp. 243-247, 1992.

[6] A. J. Ross, E. A. Jarzembowski, and S. J. Brooks, "The Cretaceous and Cenozoic record of insects (Hexapoda) with regard to global change," in Biotic response to global change: the Last 145 Million Years, S. J. Culver and p. F. Rawson, Eds., pp. 288302, Natural History Museum, Cambridge University Press, London, UK, 2000.

[7] E. A. Jarzembowski, "Palaeodiversity: equilibrium or exponential growth?" Geoscientist, vol. 11, no. 4, p. 12, 2001.

[8] C. C. Labandeira and J. J. Sepkoski, "Insect diversity in the fossil record," Science, vol. 261, no. 5119, pp. 310-315, 1993.

[9] E. A. Jarzembowski, "Palaeoentomology: towards the big picture,” Acta Zoologica Cracoviensia, vol. 46, supplement, Fossil Insects, pp. 25-36, 2003.

[10] D. Grimaldi and M. Engel, "Coleoptera and Strepsiptera," in Evolutions of the Insects, Cambridge Evolution, pp. 357-403, 2005.

[11] A. G. Ponomarenko, "Superorder Scarabaeidea Laicharting, 1781, Order Coleoptera Linné, 1758, The beetles," in History of Insects, A. p. Rasnitsyn and D. L. J. Quicke, Eds., pp. 164176, Kluwer Academic publisher, Dordrecht, The Netherlands, 2007.

[12] S. H. Lubkin and M. S. Engel, "Permocoleus, new genus, the first Permian beetle (Coleoptera) from North America," Annals of the Entomological Society of America, vol. 98, no. 1, pp. 73-76, 2005.

[13] R. J. Beckemeyer and M. S. Engel, "A second specimen of Permocoleus (Coleoptera) from the lower Permian Wellington formation of noble County, Oklahoma," Journal of the Kansas Entomological Society, vol. 81, no. 1, pp. 4-7, 2008.

[14] J. Kukalová, "Revisional study of the order Palaeodictyoptera in the Upper Carboniferous shales of Commentry, France, Part 2," Psyche, vol. 76, pp. 439-486, 1969.

[15] J. Kukalova-Peck and R. Willmann, "Lower Permian "mecopteroid-like' insects from central Europe (Insecta, Endopterygota)," Canadian Journal of Earth Sciences, vol. 27, no. 3, pp. 459-468, 1990.

[16] A. G. Ponomarenko, "Historical development of Coleoptera Archostemata," Transactions of the Paleontological Institute of the USSR Academy of Sciences, vol. 125, pp. 1-239, 1969 (Russian).

[17] J. Frenguelli, "Situación estratigráfica y edad de la "Zona con Araucarias" al sur del curso inferior del río Deseado," Boletín de Informaciones Petroleras, vol. 10, no. 112, pp. 1-54, 1933.

[18] J. Frenguelli, "Estratigrafía y edad del llamado Rético en la Argentina," Anales de la Sociedad Argentina de Estudios Geográficos, Sociedad Argentina de Estratigrafía Geológica, GAEA, vol. 8, pp. 159-310, 1948.

[19] P. N. Stipanicic and J. F. Bonaparte, "Cuenca triásica de Ischigualasto-Villa Unión (provincias de San Juan y La Rioja)," in Proceedings of the 2nd Simposio de Geología Regional Argentina, J. C. M. Turner, Ed., vol. 1, pp. 523-575, Academia Nacional de Ciencias, 1979.

[20] E. Fossa-Mancini, "Hallazgos de insectos fósiles en la América del Sur," Notas del Museo de La Plata, Paleontología, vol. 6, no. 29, pp. 101-140, 1941.

[21] E. Feruglio, Descripción Geológica de la Patagonia, Dirección General Yacimientos Petrolíferos Fiscales, Buenos Aires, Argentina, 1949. 
[22] J. F. Genise, "Upper cretaceous trace fossils in permineralized plant remains from Patagonia, Argentina," Ichnos, vol. 3, no. 4, pp. 287-299, 1995.

[23] J. F. Genise and P. L. Hazeldine, "A new insect trace fossil in Jurassic wood from Patagonia, Argentina," Ichnos, vol. 4, pp. $1-5,1995$

[24] R. G. Martins-Neto and O. F. Gallego, "A paleoentomofauna jurassica da Argentina, parte I. insetos da formação La Matilde," in Proceedings of the 15th Congresso Brasileiro de Paleontologia, p. 69, Ceará, Brazil, 1999.

[25] O. F. Gallego, M. E. Giuliano, and C. Colombi, "Nuevo registro de invertebrados en la Formación Los Rastros (Triásico Medio a Superior), Parque Provincial Ischigualasto (Provincia de San Juan), Argentina," Ameghiniana, vol. 41, no. 4, p. 11R, 2004.

[26] R. G. Martins-Neto, C. Brauckmann, O. F. Gallego, and M. J. Carmona, "The Triassic insect fauna from Argentina, Blattoptera,Glosselytrodea, Miomoptera,Auchenorrhyncha, and Coleoptera from the Los Rastros Formation (Bermejo Basin), Los Chañares locality (La Rioja Province)," Clausthaler Geowissenschaften, vol. 5, pp. 1-9, 2006.

[27] R. G. Martins-Neto, O. F. Gallego, and A. C. Mancuso, "The Triassic insect fauna from Argentina. Coleoptera from the Los Rastros Formation (Bermejo Basin), La Rioja Province," Ameghiniana, vol. 43, no. 3, pp. 591-609, 2006.

[28] R. G. Martins-Neto, O. F. Gallego, and A. M. Zavattieri, "A new Triassic insect fauna from Cerro Bayo, Potrerillos (Mendoza Province, Argentina) with descriptions of new taxa (Insecta: Blattoptera and Coleoptera)," Alcheringa, vol. 31, no. 2, pp. 199-213, 2007.

[29] R. G. Martins-Neto, O. F. Gallego, and A. M. Zavattieri, “The Triassic insect fauna from Argentina: coleoptera, hemiptera and orthoptera from the Potrerillos Formation, south of Cerro Cacheuta, Cuyana Basin," Alavesia, vol. 2, pp. 47-58, 2008.

[30] R. G. Martins-Netto, O. F. Gallego, and L. V. Tassi, "The Triassic coleopteran fauna of southern South American: morphometric variation of elytra, paleobiogeography, and a phylogenetic approach," GAEA Journal of Geociences, vol. 7, pp. 1-18, 2011.

[31] R. G. Martins-Neto and O. F. Gallego, "The Triassic insect fauna from Argentina. Blattoptera and Coleoptera from the Ischichuca Formation (Bermejo Basin), la Rioja Province," Ameghiniana, vol. 46, no. 2, pp. 361-372, 2009.

[32] M. D. Monferran, M. B. Lara, O. F. Gallego, S. C. Ballent, N. C. Cabalieri, and C. Armella, "Nuevos registros de invertebrados en la Formación Cañadón Asfalto, Depocentro Fossati (Jurásico Medio-Superior), Provincia de Chubut, Argentina," in Proceedings of the 4th Simposio Argentino del Jurásico y sus Limites, p. 33, Bahía Blanca, Argentina, 2010.

[33] C. Brauckmann, O. F. Gallego, N. Hauschke et al., "First Late Triassic record of a paleoentomofauna from South America (Malargüe Basin, Mendoza Province, Argentina)," Acta Geológica Sinica, vol. 84, no. 4, pp. 915-924, 2010.

[34] G. R. Wieland, "Rhaetic crane flies from South America," American Journal of Sciences, vol. 9, pp. 21-28, 1925.

[35] G. R. Wieland, "South American fossil insects discovery," American Journal of Sciences, Fifty Series, vol. 12, no. 68, pp. 130-135, 1926.

[36] R. J. Tillyard, "Alleged Rhaetic "Crane Flies" from South America, non Diptera but Homoptera," American Journal of Sciences, vol. 5, no. 11, pp. 265-272, 1926.

[37] A. Cabrera, "Un segundo ortóptero del Triásico argentino," E.O.S., Revista Española de Entomología, vol. 4, pp. 371-373, 1928.
[38] A. N. Zavattieri, "Aspectos Biogeográficos y paleoclimáticos de las sucesiones triásicas de Argentina, en base a registros palinológicos," Instituto Argentino de Nivología, Glaciología y Ciencias Ambientales, pp. 203-207, 2002.

[39] R. G. Martins-Neto and O. F. Gallego, "The Triassic Insect Fauna from Argentina I. Auchenorrhyncha, Miomoptera and Ensifera," Revista Española de Paleontología, vol. 14, no. 2, pp. 191-202, 1999.

[40] R. G. Martins-Neto and O. F. Gallego, "The Triassic Insect Fauna from Argentina. III. Auchenorrhyncha and Glosselytrodea," Acta Geológica Leopoldensia, vol. 24, no. 52/53, pp. 74-83, 2001.

[41] R. G. Martins-Neto and and O. F. Gallego, "Review of Dysmorphoptilidae Handlirsch (Hemiptera: Cicadomorpha) from the Argentinean Triassic, with description of a new subfamily, and a new species," Polish Journal of Entomology, vol. 75, pp. 185197, 2006.

[42] R. G. Martins-Neto, O. F. Gallego, and and R. N. Melchor, "The Triassic insect fauna from South America (Brazil, Argentina and Chile): a checklist (except Blattoptera and Coleoptera) and descriptions of new taxa," Acta Zoologica Cracoviensia, vol. 46, supplement, Fossil Insects, pp. 229-256, 2003.

[43] O. F. Gallego, L. O. Rébori, A. M. Zavattieri, N. Sinitshenkova, B. Lara, and R. G. Martins-Neto, "The most ancient Platyperlidae (Insecta-Perlida =Plecoptera) from the early Upper Triassic deposits in southern South America," Ameghiniana, vol. 48, no. 4, pp. 447-461, 2011.

[44] A. C. Mancuso, O. F. Gallego, and R. G. Martins-Neto, “The Triassic insect fauna from the Los Rastros Formation (Bermejo Basin), La Rioja Province (Argentina): its context, taphonomy and paleobiology," Ameghiniana, vol. 44, no. 2, pp. 337-348, 2007.

[45] R. G. Martins-Neto, A. Mancuso, and O. F. Gallego, "The Triassic insect fauna from Argentina. Blattoptera from the Los Rastros Formation (Bermejo Basin), La Rioja Province," Ameghiniana, vol. 42, no. 4, pp. 705-723, 2005.

[46] R. N. Melchor, "Sequence Stratigraphy Analysis of Lacustrine Facies in a Half-Graben: example from the Triassic Ischigualasto Villa Unión Basin (Argentina)," in Proceedings of the 6th Congreso de Exploracion y Desarrollo de Hidrocarburos, IAPG, Actas, p. 14, Mar del Plata, Argentina, 2005.

[47] R. N. Melchor, "Changing lake dynamics and sequence stratigraphy of synrift lacustrine strata in a half-graben: an example from the Triassic Ischigualasto-Villa Unión Basin, Argentina," Sedimentology, vol. 54, no. 6, pp. 1417-1446, 2007.

[48] R. G. Martins-Neto and O. F. Gallego, "The Triassic Insect Fauna from Argentina. IV. Glosselytrodea and complements on Auchenorrhyncha," Acta Geologica Leopoldensia, vol. 24, no. 52/53, pp. 105-114, 2001.

[49] O. F. Gallego and R. G. Martins-Neto, "La entomofauna mesozoica de la Argentina: Estado actual del conocimiento," Revista de la Sociedad Entomológica Argentina, vol. 58, no. 1-2, pp. 8694, 1999.

[50] R. G. Martins-Neto and O. F. Gallego, "Nuevos Artrópodos de la Formación La Matilde, Gran Brajo de San Julián (Provincia de Santa Cruz), Argentina," in Proceedings of the 6th Congreso Argentino de Paleontología y Bioestratigrafia, pp. 62-63, Chubut, Argentina, 1994.

[51] M. D. Monferran, J. F. Genise, and O. F. Gallego, "Capullos fósiles de Tricópteros del Jurásico Medio a Superior de la Patagonia Argentina," in Proceedings of the 7th Congreso Argentino de Entomología, p. 230, Córdoba, Argantina, 2008. 
[52] M. D. Monferran, O. F. Gallego, and J. F. Genise, "Nuevos datos sobre los capullos fósiles (Trichoptera) del Jurásico de la Patagonia Argentina," Comunicaciones Científicas y Técnicas 2009, Secretaría General de Ciencia y Técnica de la UNNE, 2009, http://www.unne.edu.ar/investigacion/com2009/CB-030.pdf.

[53] J. F. Genise, O. F. Gallego, R. N. Melchor, and S. deValais, "Capullos fósiles de tricópteros (Conchindusia isp.) (Insecta) construidos con valvas de conchóstracos del Jurásico de la Patagonia, Argentina," in Proceedings of the 8th Congreso Argentino de Paleontología y Bioestratigrafía, Corrientes, Argentina, 2002, Resúmenes 93.

[54] O. F. Gallego, N. G. Cabaleri, C. Armella et al., "Paleontology, sedimentology and paleoenvironment of a new fossiliferous locality of the Jurassic Cañadón Asfalto Formation, Chubut Province, Argentina," Journal of South American Earth Sciences, vol. 31, pp. 54-68, 2011.

[55] M. Andrade-Morraye and J. Genise, "An association of fossil larval tubes and head capsules of Chironomidae (Diptera) from the Jurassic (Callovian-Oxfordian) Cañadon Asfalto Formation, Patagonia, Argentina," in Proceedings of the Fossils X3, p. 5, Pretoria, South Africa, 2005.

[56] J. F. Petrulevicius, "A new species of Bittacidae sensu lato (Mecoptera) from the Callovian-Oxfordian: new Jurassic locality of insect body fossils from Patagonia, Argentina," in Proceedings of the 4th International Congress of Paleoentomology, p. 275, Diputación Forai de Álava, Vitoria-Gasteiz, Spain, 2007.

[57] J. L. Panza and M. V. Irigoyen, "Hoja Geológica 4969-IV Puerto San Julián, escala 1:250.000, provincia de Santa Cruz," Boletín de la Dirección Nacional del Servicio Geológico, vol. 211, pp. $1-78,1995$.

[58] N. G. Cabaleri, D. Silva Nieto, C. Armella et al., "Estratigrafía, análisis de facies y paleoambientes de la Formación Cañadón Asfalto en el Depocentro Jurásico de cerro Cóndor, Provincia del Chubut," Revista de la Asociación Geológica Argentina, vol. 66, no. 2, pp. 349-367, 2010.

[59] N. C. Cabaleri, C. Benavente, M. D. Monferran, and O. F. Gallego, "Sedimentology, paleontology and paleoenvironments of the Jurassic Cañadón Asfalto Formation at Fossati depocenter, Chubut province, Argentina," Sedimentology. In press.

[60] G. Cladera, R. Andreis, S. Archangelsky, and R. Cúneo, "Baqueró Group stratigraphy, Patagonia (Santa Cruz Province, Argentina)," Ameghiniana, vol. 39, no. 1, pp. 3-20, 2002.

[61] I. D. Pinto, "A new lower Cretaceous Blattoid insect from Argentina," Pesquisas, vol. 17, no. 1-2, pp. 11-14, 1990.

[62] J. F. Petrulevičius and A. Nel, "Frenguelliidae, a new family of dragonflies from the earliest Eocene of Argentina (Insecta: Odonata): phylogenetic relationships within Odonata," Journal of Natural History, vol. 37, no. 24, pp. 2909-2917, 2003.

[63] M. B. Prámparo, "Lower Cretaceous palynoflora of the La Cantera Formation, San Luis Basin: correlation with other Cretaceous palynofloras of Argentina," Cretaceous Research, vol. 15, no. 2, pp. 193-203, 1994.

[64] A. B. Arcucci, D. Rivarola, M. Pramparo et al., "Update of the paleofaunistic and paleofloristic diversity of La Cantera Formation (Early Cretaceous, San Luis): a lacustrine environment in Central Argentina," in Gondwana 12 "Geological and Biological Heritage of Gondwana", Resúmenes, Mendoza, Argentina, 2005.

[65] J. F. Petrulevičius, A. Nel, and A. S. Sallenave, "Recent genus notonecta (Insecta: Heteroptera: Notonectidae) in the lower cretaceous of San Luis, Argentina: palaeoecological implications," Annales de la Societe Entomologique de France, vol. 46, no. 1-2, pp. 247-253, 2010.
[66] A. F. Mazzoni, "Notonectidae (Hemiptera, Heteroptera) de la Formación La Cantera, (Cretácico Inferior), Provincia de San Luis, Argentina," Boletín de la Academia Nacional Ciencias, vol. 56, pp. 259-273, 1985.

[67] A. F. Mazzoni and M. Hünicken, "Corixidae (Insecta, Heteroptera) en el Cretácico Inferior de la Sierra del Gigante, San Luis, Argentina," in Proceedings of the Reunión de Comunicaciones Científicas sobre Investigaciones Paleontológicas en el NOA APA, Salta, Argentina, 1984.

[68] A. G. Ponomarenko, "Beetles (Insecta, Coleoptera) of the Late Permian and Early Triassic," Paleontological Journal, vol. 38, supplement 2, pp. 185-196, 2004.

[69] I. D. Pinto, "Permian Insects from the Parana Basin, South Brazil. I. Mecoptera," Revista Brasileira de Geociências, São Paulo, vol. 2, no. 2, pp. 105-116, 1972.

[70] I. D. Pinto, "Permian insects from the Paraná Basin, South Brazil. IV-Homoptera-2-Cicadidae," Pesquisas, Porto Alegre, vol. 19, pp. 13-22, 1987.

[71] I. D. Pinto and L. Ornellas, "A new insect Triassoblatta cargnini Pinto et Ornellas, sp. nov., a Triassic Blattoid from Santa Maria Formation, South Brazil," Anais da Academia Brasileira de Ciências, vol. 46, pp. 515-521, 1974.

[72] R. G Martins-Neto, "Conan barbarica n. gen. et n. sp., (Insecta, Coleoptera, Coptoclavidae) uma gigantesca larva da Formação Santana, Bacia do Araripe (Cretáceo Inferior)," Nordeste do Brasil, Revista Geociências, UNESP, vol. 17, no. 1, pp. 109-114, 1998.

[73] R. G Martins-Neto, "Review of some insecta from Mesozoic and Cenozoic Brazilian deposits with descriptions of new taxa," Acta Geológica Leopoldensia, vol. 24, no. 52/53, pp. 115124, 2001.

[74] M. A. Vulcano and F. S. Pereira, "Entomofauna fóssil da Chapada do Araripe, Ceará, Brasil-Cretaceimelittomoides cearensis gen. nov. sp. nov. (Coleoptera: Pyrochroidae)," in Proceedings of the Congresso Brasileiro de Paleontologia, p. 27, Rio de Janeiro, Brasil, 1987.

[75] V. V. Zherikhin and V. G. Gratshev, "Fossil curculionoid beetles (Coleoptera, Curculionoidea) from the Lower Cretaceous of the northeastern Brazil," Paleontological Journal, vol. 38, no. 5, pp. 528-537, 2004.

[76] R. G. Martins-Neto, “A Paleoentomofauna da Formação Tremembé (Bacia de Taubaté) Oligoceno do Estado de São Paulo: novos Hemiptera, Hymenoptera, Coleoptera, Auchenorrhyncha e Lepidoptera," Revista Universidade Guarulhos, Série Geociências, vol. 3, no. 6, pp. 58-70, 1998.

[77] R. G. Martins-Neto, "Review of some insecta from Mesozoic and Cenozoic Brazilian deposits with descriptions of new taxa," Acta Geológica Leopoldensia, vol. 24, no. 52/53, pp. 115$124,2001$.

[78] R. G. Martins-Neto and M. Mendes, "The Fonseca Formation paleoentomofauna (Fonseca Basin, Oligocene of Minas Gerais State, Brazil) with description of new taxa," Acta Geologica Leopoldensia, vol. 25, no. 55, pp. 27-33, 2002.

[79] F. Murature de Sureda and R. N. Alonso, "Nuevos hallazgos de insectos fósiles en la Formación Lumbrera (Grupo Salta, Cretácico-Terciario) en la provincia de Salta, República Argentina," in Proceedings of the Actas II Congreso Argentino de Paleontología y Bioestratigrafía, I Congreso Latinoamericano de Paleontología, pp. 127-129, 1980.

[80] T. D. A. Cockerell, “Tertiary insects from Argentina," Proceedings of The United States National Museum, vol. 68, no. 1, pp. 1-5, 1925. 
[81] T. D. A. Cockerell, “Tertiary insects from Argentina," Nature, no. 116, pp. 711-712, 1925.

[82] T. D. A. Cockerell, “Tertiary insects from Argentina," American Journal of Science, vol. 5, no. 11, pp. 501-504, 1926.

[83] T. D. A. Cockerell, "The fauna of the Sunchal (Margas Verdes) Formation, Northern Argentina," American Museum Novitates, no. 886, pp. 1-9, 1936.

[84] O. Schlagintweit, "Los insectos fósiles del Norte argentino y la edad del Horizonte Calcáreo-Dolomítico," Boletín de Informaciones Petroleras, vol. 13, no. 145, pp. 61-69, 1936.

[85] E. F. G. Díaz,, "La edad de la Formación Ventana en el área al norte y al este del lago Nahuel Huapi," Revista de la Asociación Geológica Argentina, vol. 34, no. 2, pp. 113-124, 1979.

[86] L. M. Anzotegui, S. S. Garralla, L. S. Morton, J. M. Robledo, and R. Herbst, "Paleontología de la Formación Palo Pintado (Mioceno Superior) en la localidad de Peñas Blancas (Salta, Argentina)," in Proceedings of the Reunion Anual de Comunicaciones de la Asociación Paleontológica Argentina, 2011.

[87] O. F. Gallego, R. G. Martins-Neto, and S. N. Nielsen, "Conchostracans and insects from the Upper Triassic of the Biobío river ("Santa Juana Formation" ), south-central Chile," Revista Geologica de Chile, vol. 32, no. 2, pp. 293-311, 2005.

[88] G. Kuschel, "Un curculionido del Cretácico Superior- Primer insecto fósil de Chile," Centro de Investigaciones Zoológicas, Universidad de Chile, no. 5, pp. 49-54, 1959.

[89] C. S. Churcher, "The insect fauna from the Talara tar-seeps, Peru," Canadian Journal of Zoology, vol. 44, no. 6, pp. 985-993, 1966. 

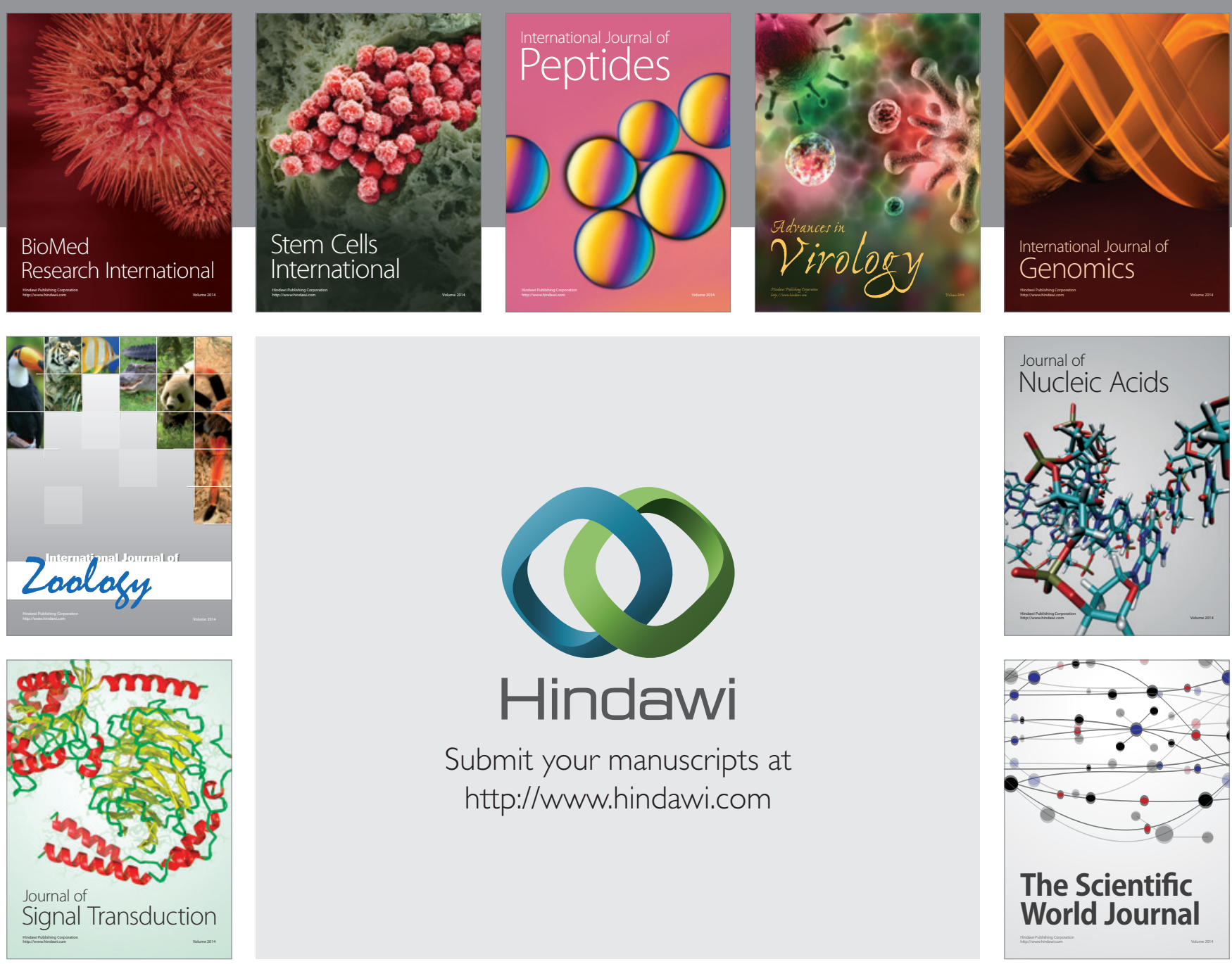

Submit your manuscripts at

http://www.hindawi.com
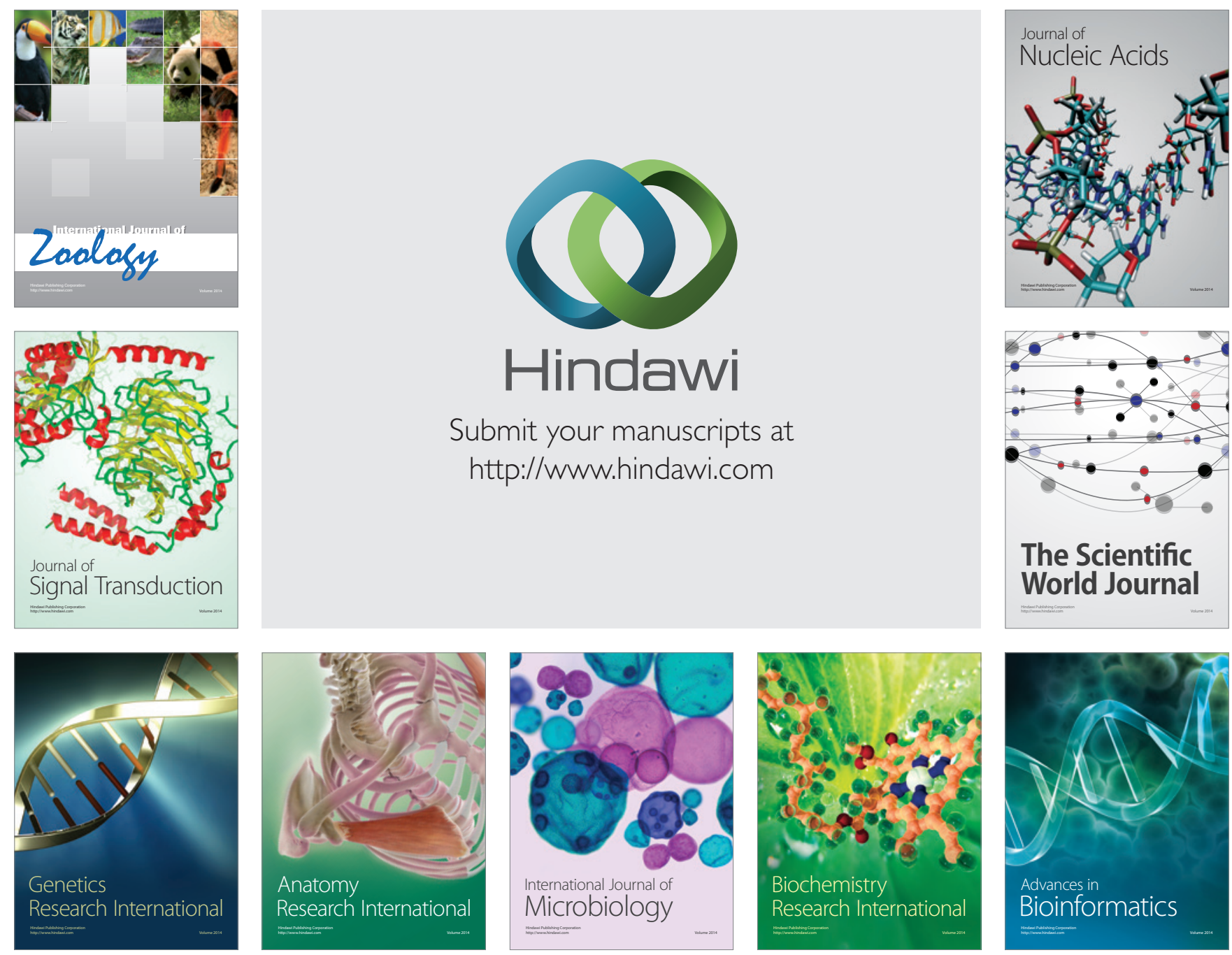

The Scientific World Journal
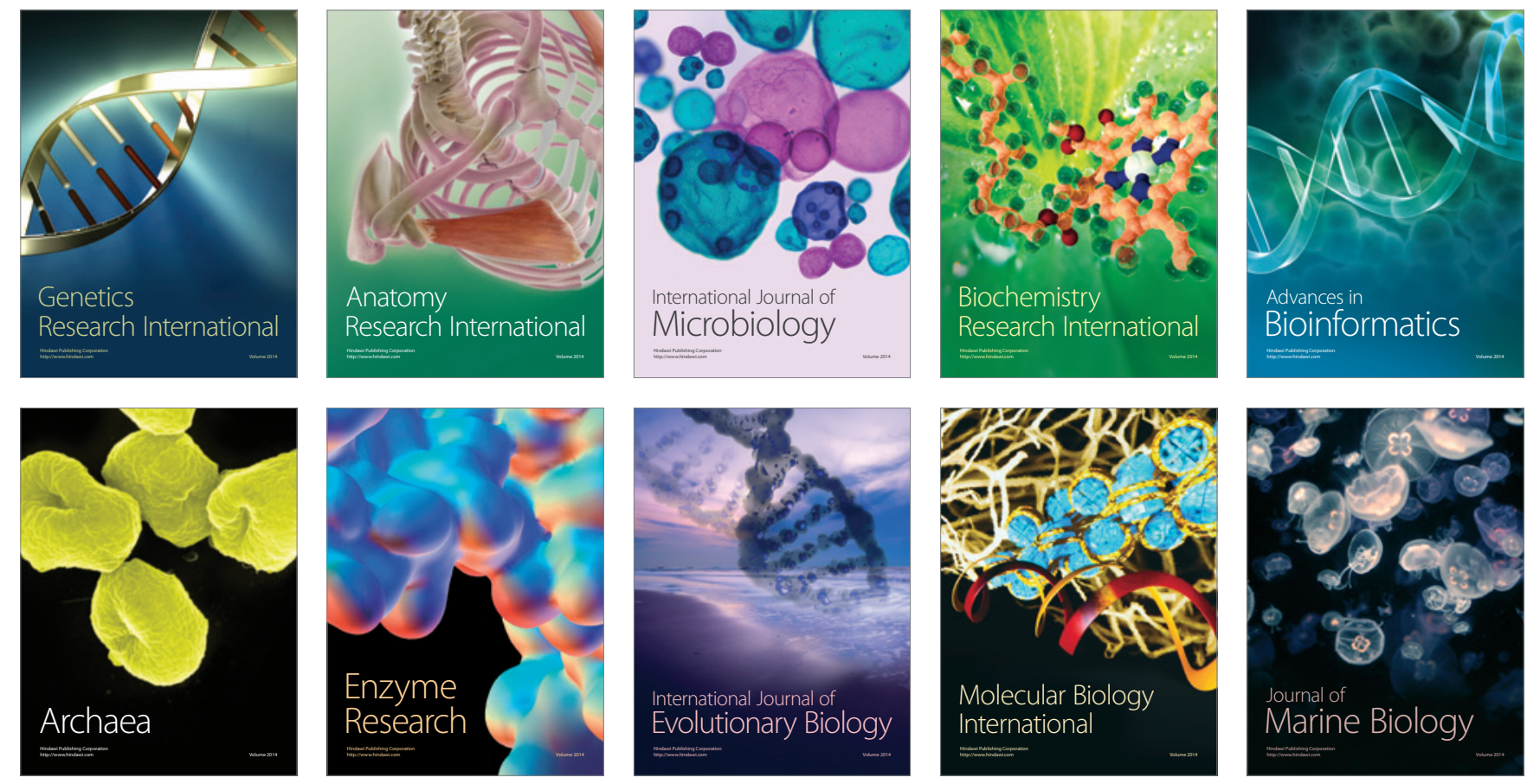